\title{
Specificity of Prehaustorial Resistance to Puccinia hordei and to Two Inappropriate Rust Fungi in Barley
}

\author{
T. J. H. Hoogkamp, W.-Q. Chen, and R. E. Niks
}

Graduate School of Experimental Plant Sciences, Department of Plant Breeding, Wageningen Agricultural University, P.O. Box 386, 6700 AJ Wageningen, the Netherlands.

Current address of W.-Q. Chen: Institute of Plant Protection, CAAS, West Yuan Ming Yuan Road, Beijing 100094, PR China.

Accepted for publication 4 May 1998.

\section{ABSTRACT}

Hoogkamp, T. J. H., Chen, W.-Q., and Niks, R. E. 1998. Specificity of prehaustorial resistance to Puccinia hordei and to two inappropriate rust fungi in barley. Phytopathology 88:856-861.

To elucidate the specificity of prehaustorial resistance to inappropriate rust fungi, we studied two populations of recombinant inbred lines of barley that segregated for partial resistance (PR) to Puccinia hordei and for the resistance to the inappropriate rust species $P$. recondita $\mathrm{f}$. sp. tritici and $P$. hordei-murini. PR to $P$. hordei is prehaustorial and nonhypersensitive, and its level can be assessed accurately by measuring the latent period of the fungus. The resistance to the inappropriate rust species is a combination of prehaustorial (nonhypersensitive) and posthaustorial (hypersensitive) mechanisms. The amount of nonhypersensitive, early abortion of $P$. recondita f. sp. tritici and $P$. hordei-murini sporelings reflects the degree of prehaustorial defense to the two inappropriate rust species. All lines showing a long latent period of $P$. horde $i$ also had a relatively high level of early abortion of the growth of $P$. recondita f. sp. tritici and $P$. hordei-murini. This indicates that genes for PR to $P$. hordei are also effective against these two inappropriate rust species. The reverse was not necessarily true; some lines showing a high level of early abortion of $P$. recondita f. sp. tritici and $P$. hordei-murini had a low level of PR to $P$. hordei. Moreover, lines with a similar level of prehaustorial resistance to $P$. recondita f. sp. tritici could differ considerably in their prehaustorial resistance to $P$. hordei-murini. This indicates that genes for prehaustorial resistance may exhibit rust species specificity.
Cereals and grasses are hosts for several rust species that may cause economically significant losses. An intriguing feature of the rust fungi is their extreme host specificity. Most rust species or formae speciales can only infect one or a few closely related grass species. It is still unclear which factors are responsible for the high degree of specialization of the rust fungi. Several models on the evolution, genetics, and molecular basis of the nonhost resistance have been proposed $(3,4,7,9,10,24,36)$, but the experimental testing of these concepts is difficult. The problem for studies on the genetics of resistance to inappropriate pathogen species is the small intraspecific variation for this trait. Usually, no individual of the plant species is susceptible to any genotype of the inappropriate rust species.

Zhang et al. (41) proposed to use cultivated barley (Hordeum vulgare L.) as a model crop for the investigation of the genetics and mechanisms of resistance to inappropriate rust fungi. In this plant species, low frequencies of moderate susceptibility to some inappropriate rust fungi have been found (26). Barley may be considered an "intermediate host species" for these rust species (23). On the basis of a screening of 212 cultivated barley accessions, it was observed that the wheat leaf rust fungus (Puccinia recondita Roberge ex Desmaz. f. sp. tritici) reproduced to some extent on about $16 \%$ of the accessions tested, and the leaf rust (P. hordeimurini Buchwald) of wall barley $(H$. murinum L.) on $8 \%$. In most cases, this infection was confined to only a few pustules per leaf, despite a high dose of inoculum. Neither of the two rust species is known to cause epiphytotics on cultivated barley $(1,16)$. The low frequencies and low levels of susceptibility in barley to these two rust fungi allow genetic studies. Elucidation of the genetics and

Corresponding author: R. E. Niks; E-mail address: Rients.Niks@ users.pv.wau.nl

Publication no. P-1998-0625-01R

(C) 1998 The American Phytopathological Society mechanism of resistance to these inappropriate rust species may provide clues to the understanding of nonhost resistance.

There is still relatively little known about the genetics of resistance to inappropriate rust and powdery mildew fungi. There is evidence that in some plant pathosystems the resistance to inappropriate formae speciales is governed by major genes $(12,17,33$, $40)$ that cause a hypersensitive response to the fungus $(18,37,38)$. Tosa (35) found evidence that in such hypersensitivity resistance a gene-for-gene relationship operates, similar to that of race-specific hypersensitivity resistance in host species to their pathogens. In the resistance of barley to inappropriate rust fungi, a hypersensitive response also may occur $(20,41)$. This hypersensitivity may be governed by major genes for resistance and avirulence, as those purported by Tosa (36) in wheat to inappropriate formae speciales of the powdery mildew fungus (Erysiphe graminis).

In many plant species, another mechanism of defense (nonhypersensitive and prehaustorial) occurs in which haustorium formation by the inappropriate rust or powdery mildew species or forma specialis is prevented $(5,6,8,11,13-15,22,37,39)$. The genetic basis of the prehaustorial resistance is yet unknown.

In barley, both mechanisms seem to occur in the interaction with the two inappropriate rust species $P$. recondita f. sp. tritici and $P$. hordei-murini $(20,29,41)$. The majority of sporelings of $P$. recondita $\mathrm{f}$. $\mathrm{sp}$. tritici and $P$. hordei-murini in barley seedlings are arrested prehaustorially. This results in early abortion without plant cell necrosis. However, a certain proportion of sporelings may establish one or more haustoria, but most of those established sporelings will sooner or later elicit a posthaustorial hypersensitive response (20). This hypersensitivity may be macroscopically visible if it surrounds rather large rust colonies, resulting in low to medium infection types (41).

We are especially interested in the prehaustorial component of the resistance to inappropriate rust fungi. At the microscopic level, this resistance resembles the partial resistance $(\mathrm{PR})$ of barley to the barley leaf rust fungus (P. hordei G. Otth) $(20,22)$. This PR is 
quantitative and largely race nonspecific (31). The higher the level of PR in a barley line, the lower the rate of haustorium formation by the leaf rust fungus. Poor haustorium formation leads to a high level of early abortion and a slow growth of those infection units that successfully establish. This slow growth results in a long latent period (LP) $(21,22)$. The similarity in the mechanism of PR to barley leaf rust and the prehaustorial reaction to inappropriate rust fungi raises the question whether genes for PR are also part of the defense system of barley to inappropriate rust fungi. Additional evidence is provided by the fact that the barley line L94 with the highest level of susceptibility to $P$. hordei, i.e., devoid of genes for $\mathrm{PR}$, is also relatively susceptible to the two inappropriate rust species $P$. recondita f. sp. tritici and $P$. hordei-murini (26).

Zhang et al. (41) studied $\mathrm{F}_{8}$ lines derived from the barley crosses L94 × 'Vada' and L94 × C-123. 'Vada' and C-123 have a high level of PR to $P$. hordei and are completely resistant to both inappropriate rust species. In both sets of $F_{8}$ lines, the segregation for the level of PR to $P$. hordei was moderately associated with that for the level of resistance to $P$. recondita f. $\mathrm{sp}$. tritici and $P$. hordei-mur$i$ ini. However, lines with low PR to $P$. hordei were not always relatively susceptible to the two inappropriate rust species. We presume that in the macroscopic evaluation by Zhang et al. (41) early posthaustorial hypersensitivity resistance might have masked the association between the prehaustorial resistance to the three rust species.

The purpose of the current research was to quantify, by microscopical evaluations, the prehaustorial resistance against the two inappropriate rust species in the $\mathrm{F}_{8}$ lines. Quantification of the prehaustorial resistance allowed determination of the rust species specificity of prehaustorial resistance in barley.

\section{MATERIALS AND METHODS}

Plant material. $\mathrm{F}_{8}$ lines obtained by single-seed descent from the crosses L94 $\times$ 'Vada' and L94 $\times$ C-123, as studied by Zhang et al. (41), were propagated to $\mathrm{F}_{9}$ and considered as recombinant inbred lines (RILs). Line L94 is extremely susceptible to $P$. hordei and moderately susceptible to $P$. recondita f. sp. tritici and $P$. hordei-murini. 'Vada' and C-123 have a high level of PR to P. hordei (28) and are resistant to $P$. recondita f. sp. tritici and $P$. hordeimurini $(20,41)$.

From about $100 \mathrm{~F}_{8}$ lines per cross, 37 and $44 \mathrm{~F}_{9}$ lines, respectively, were selected. About 60 relatively uninformative lines with an intermediate relative LP (RLP) to $P$. hordei were not selected (41). Two lines from the cross L94 $\times$ 'Vada' studied by Zhang et al. (41) were missing because of lack of seed. The wheat (Triticum aestivum) cultivar Adonis and a susceptible line of $H$. murinum (collected at Rhenen, the Netherlands) were used as the appropriate susceptible hosts to $P$. recondita f. sp. tritici and $P$. hordeimurini, respectively.

Pathogen isolates and inoculation. The isolate Flamingo of $P$. recondita $\mathrm{f}$. $\mathrm{sp}$. tritici and a field isolate of $P$. hordei-murini, collected at Rhenen, the Netherlands, were maintained on wheat cv. Little Club and the susceptible line of $H$. murinum (collected at Rhenen, the Netherlands), respectively. Urediospores produced on these plants were stored in liquid nitrogen. The inoculations were carried out with freshly collected spores supplemented with spores from the liquid nitrogen storage to obtain a sufficient amount of inoculum. The inoculum was mixed with Lycopodium spores (about $1: 10, \mathrm{vol} / \mathrm{vol}$ ) and applied in a settling tower (19).

Seedlings were grown in boxes $(37 \times 39 \mathrm{~cm})$. Each box contained seedlings of five RILs $\left(\mathrm{F}_{9}\right)$, the two parental lines, and the appropriate susceptible host. Each line in the box was represented by four or five seedlings in a row. The adaxial surfaces of the primary leaves were inoculated with 270 to 300 urediospores per $\mathrm{cm}^{2}$. The plants were incubated in a greenhouse compartment at $100 \%$ relative humidity during the first night $(16 \mathrm{~h})$. The next morning, the boxes were transferred to a compartment with a $28 / 25^{\circ} \mathrm{C}$ (day/ night) temperature (41).
Histological evaluation of the pathogenesis. Six or seven days after inoculation, when the colonies on L94 started to sporulate, three out of five leaf segments of 2 to $3 \mathrm{~cm}^{2}$ were randomly collected from each line. These leaves were fixed, cleared by boiling for $1.5 \mathrm{~min}$ in lactophenol/ethanol $(1: 2, \mathrm{vol} / \mathrm{vol})$, and stored overnight in this mixture at room temperature. Specimens were then washed twice for $15 \mathrm{~min}$ each with $50 \%$ ethanol and $0.05 \mathrm{M}$ $\mathrm{NaOH}$, washed three times with water, and placed in $0.1 \mathrm{M}$ Tris-

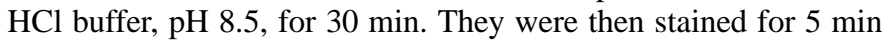
with a $0.1 \%$ solution of Uvitex 2B 200\% (Ciba-Geigy A.G., Basel, Switzerland) $(19,20)$ in this buffer for fluorescence microscopy (34). The observations were carried out with Zeiss Axiophot photomicroscope (with HBO 50-W light source; Carl Zeiss B.V., Weesp, the Netherlands) with an aniline blue filter (Zeiss 05: exciter filter BP395-440, barrier filter LP470; Carl Zeiss, Inc.) under $\times 125$ to $\times 500$ magnification.

At least 33 infection units were evaluated on each of the three leaf segments and classified according to their stage of development $(20,27,29)$. Infection units that were arrested after the formation of the primary infection hyphae and before the formation of, at most, six branches per infection hypha were classified as "early aborted." Yellow autofluorescence of plant cells in direct association with infection units was recorded as "necrosis" (29). Such autofluorescence has been demonstrated to occur after the formation of a haustorium $(21,25)$, and hence, indicates posthaustorial resistance. Infection units were considered "established" when the only infection hypha ( $P$. recondita $\mathrm{f}$. sp. tritici) or at least one of the two infection hyphae ( $P$. hordei-murini and $P$. hordei) had seven or more branches. Infection sites that developed from doubly penetrated stomata were ignored.

The experiment was carried out in three consecutive replications. Per barley line, the data on early abortion are based on $\sim 33$ (infection units) $\times 3$ (leaves) $\times 3$ (replications) $\approx 300$ infection units. The percentage of early aborted infection units without necrosis was calculated by dividing the number of these infection units by the number of early aborted and established infection units $\times 100 \%$.

Verification experiment. Out of the 81 lines investigated, two lines from the cross L94 $\times \mathrm{C}-123$ and three lines from the cross L94 $\times$ 'Vada' represented clear examples of line $\times$ rust species interaction. These lines were subjected to a verification experiment. The lines, their parents, and the appropriate susceptible host lines were sown, inoculated with the two inappropriate rust species, and evaluated as described above. This verification trial was carried out in two ( $P$. hordei-murini) or three ( $P$. recondita f. sp. tritici) consecutive replications. The lines were also tested for early abortion and LP of $P$. hordei isolate 121 in three replications. The LP was converted to a value relative to the LP on L94 (= 100\%) (41).

\section{RESULTS}

Prehaustorial resistance to $P$. recondita f. sp. tritici and $P$. hordei-murini. To quantify the prehaustorial resistance to the two inappropriate rust species, we determined the percentage of early abortion without necrosis of $P$. recondita f. sp. tritici and $P$. hordei-murini. Such early abortion without necrosis of plant cells indicates that the fungus had not been able to develop a haustorium, and hence, reflects prehaustorial resistance $(21,25)$. In the leaf segments prepared for UV microscopy, we observed infection units of $P$. recondita $\mathrm{f}$. sp. tritici and $P$. hordei-murini in various stages of development as described by Niks and Kuiper (27) and Niks and Rubiales (29). On the barley parents and the 81 RILs, we observed that the percentage of early abortion without necrosis in L94 was, on average, almost 10 times as high as in the susceptible host (Table 1). In 'Vada' and C-123, this percentage was again much higher, i.e., at least $80 \%$. In the RILs, the percentage of early aborted infection units without necrosis ranged from somewhat lower than in L94 to as high as in 'Vada' and C-123 (Fig. 1A and B). We conclude that the three barley parental lines show genetic variation in 
the level of prehaustorial resistance to the two inappropriate rusts and that this variation is inherited quantitatively.

Posthaustorial resistance to $P$. recondita f. sp. tritici and $P$. hordei-murini. In the parental lines and in the RILs, a variable proportion of infection units were arrested early in association with a very early hypersensitive reaction. For example, in the RILs from the cross L94 × 'Vada' tested with $P$. hordei-murini, about 2 to $45 \%$ of the infection units were arrested due to such an early hypersensitivity (data not shown). This variation was independent from the variation between the RILs in early abortion without necrosis of plant cells. In most barley RILs, at least a few infection units had developed to large, macroscopically visible infections associated with hypersensitivity. Such large established infection units could even have started to produce sporogenic tissue. We conclude that, in resistance of barley to these two inappropriate rust fungi, pre- and posthaustorial mechanisms both play a role.

Correlation between the prehaustorial resistance to $P$. recondita f. sp. tritici and to $\boldsymbol{P}$. hordei-murini. The RILs are progeny from the crosses that have the advantage of showing fixed recombination of the resistance genes in the parents (2). Cosegregation of resistance to the rust species would suggest that the genes are effective to more than one rust species or that rust species-specific genes tend to be closely linked.

We quantified the association in prehaustorial resistance to the two inappropriate rust species by the Spearman's coefficient of rank correlation. The prehaustorial resistance to the two inappropriate rust fungi was significantly and rather highly associated in both populations of RILs (Table 2, Fig. 1A and B). Most lines in which a relatively high level of early abortion occurred to one of the inappropriate rusts also showed a high level of prehaustorial

TABLE 1. Percentage of early abortion without plant cell necrosis of sporelings of two inappropriate rust species in three barley lines

\begin{tabular}{lcc}
\hline Genotype & $\begin{array}{c}\text { Puccinia recondita } \\
\text { f. sp. tritici }\end{array}$ & $\begin{array}{c}\text { Puccinia } \\
\text { hordei-murini }\end{array}$ \\
\hline Hordeum vulgare (line L94) & $43.9^{\mathrm{a}}$ & $34.5^{\mathrm{a}}$ \\
Hordeum vulgare (cv. Vada) & $81.0^{\mathrm{b}}$ & $91.5^{\mathrm{b}}$ \\
Hordeum vulgare (line C-123) & $94.7^{\mathrm{b}}$ & $90.0^{\mathrm{b}}$ \\
Triticum aestivum (cv. Adonis) $^{\mathrm{c}}$ & $4.4^{\mathrm{a}}$ & $\ldots$ \\
Hordeum murinum $^{\mathrm{c}}$ & $\ldots$ & $4.4^{\mathrm{a}}$
\end{tabular}

a Average of six consecutive replications, each consisting of at least 100 infection units.

b Average of three consecutive replications, each consisting of at least 100 infection units.

c $T$. aestivum (cv. Adonis) and H. murinum (collected at Rhenen, the Netherlands) served as controls susceptible to $P$. recondita f. $\mathrm{sp}$. tritici and $P$. hordei-murini, respectively. resistance to the other rust species. This suggests that the genes responsible for resistance are effective to more than one rust species or that rust species-specific genes are closely linked. However, the set of RILs derived from L94 $\times$ 'Vada' gave indications of rust species specificity (Fig. 1A). Lines K4-90 and K4-109 from this cross, examined in the verification experiment (Table 3), had about an equal level of prehaustorial resistance to $P$. recondita f. sp. tritici, but differed greatly in their prehaustorial resistance to P. hordei-murini (Table 3, Fig. 1A). The line K4-52, which was also included in the verification experiment, had a level of prehaustorial resistance to $P$. recondita f. sp. tritici similar to L94, but a considerably higher level of resistance to $P$. hordei-murini (Table 3, Fig. 1A). Apparently, the genes for prehaustorial resistance are not equally effective to the two inappropriate rust species.

Correlation between LP of $\boldsymbol{P}$. hordei and prehaustorial resistance to $\boldsymbol{P}$. recondita f. sp. tritici and $\boldsymbol{P}$. hordei-murini. We also quantified the association in prehaustorial resistance against the two inappropriate rust species with the level of PR against $P$. hor$d e i$ by the Spearman's coefficient of rank correlation. We used the measurements of the RLP of $P$. horde $i$ on the $\mathrm{F}_{8}$ lines, as presented in Zhang et al. (41), as a parameter for the prehaustorial PR to $P$. hordei (discussed above). This parameter is the LP expressed as a relative value to the LP measured on the susceptible line L94 in the same plant box.

The correlation between RLP of $P$. hordei and the prehaustorial resistance to $P$. recondita $\mathrm{f}$. $\mathrm{sp}$. tritici and $P$. hordei-murini were both positive and significant (Table 2, Fig. 2A to D). These corre-

TABLE 2. Association between the prehaustorial resistance to Puccinia horde ${ }^{\mathrm{a}}$ and to two inappropriate rust species ${ }^{\mathrm{b}}$ in recombinant inbred lines from two barley crosses

\begin{tabular}{|c|c|c|}
\hline \multirow[b]{2}{*}{ Correlation between } & \multicolumn{2}{|c|}{ Cross } \\
\hline & L94 × 'Vada'c & $\mathrm{L} 94 \times \mathrm{C}-123^{\mathrm{d}}$ \\
\hline $\operatorname{RLP}^{\mathrm{e}}(P$. hordei $) \&$ PEA ( $P$. recondita f. sp. tritici) & $0.69^{* * \mathrm{f}}$ & $0.49^{* *}$ \\
\hline $\mathrm{RLP}^{\mathrm{e}}(P$. hordei $) \& \mathrm{RIF}^{\mathrm{e}}$ (P. recondita f. sp. tritici) & $-0.62^{* *}$ & $-0.53^{* *}$ \\
\hline $\operatorname{RLP}^{\mathrm{e}}(P$. hordei $) \& \operatorname{PEA}(P$. hordei-murini $)$ & $0.73^{* * *}$ & $0.38^{*}$ \\
\hline $\operatorname{RLP}^{\mathrm{e}}(P$. hordei $) \& \mathrm{RIF}^{\mathrm{e}}(P$. hordei-murini $)$ & -0.24 & -0.29 \\
\hline PEA $(P$. recondita f. sp. tritici $) \&$ PEA ( $P$. hordei-murini $)$ & $0.66^{* *}$ & $0.73^{* *}$ \\
\hline $\operatorname{RIF}^{\mathrm{e}}\left(P\right.$. recondita f. sp. tritici) \& $\operatorname{RIF}^{\mathrm{e}}(P$. hordei-murini $)$ & $0.57^{* * *}$ & $0.57^{* *}$ \\
\hline
\end{tabular}

a Resistance measured as relative latent period (RLP) relative to L94 (=100\%), latent period is the major component of partial resistance and due to a prehaustorial resistance mechanism (22).

${ }^{\mathrm{b}}$ Resistance measured as the percentage of early abortion (PEA) without necrosis in $\mathrm{F}_{9}$ lines or as relative infection frequency (RIF) to L94 $(=100 \%)$ of uredia and flecks on $\mathrm{F}_{8}$ lines.

c Spearman's rank correlation based on 37 lines.

d Spearman's rank correlation based on 44 lines.

e Macroscopic observations by Zhang et al. (41).

$\mathrm{f}^{*}$ and ${ }^{* *}$ indicate a significant correlation at the 1 and $0.1 \%$ level, respectively.
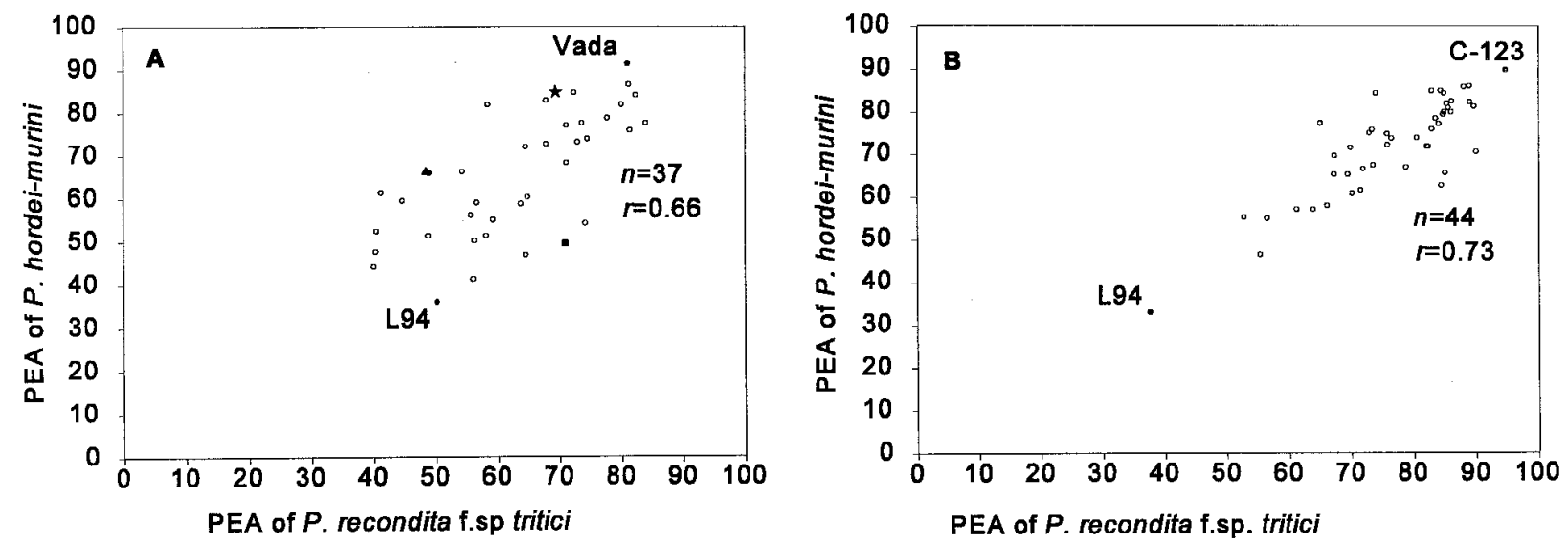

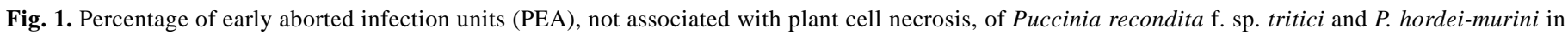

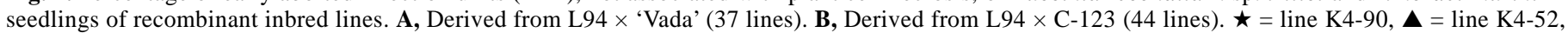
and $\mathbf{\square}=$ line K4-109. 
lation coefficients were particularly high for the RILs derived from L94 × 'Vada' (Fig. 2A and B). This suggests that the genes for PR to $P$. hordei in 'Vada' also act as or are linked to genes for resistance to the inappropriate rust species.

In the RILs derived from L94 × C-123, the association was much weaker (Fig. 2C and D). In some very susceptible RILs (i.e., a RLP of $P$. hordei similar to that on L94), we recorded a very high level of early abortion without necrosis of $P$. recondita $\mathrm{f}$. $\mathrm{sp}$. tritici and P. hordei-murini. Two such lines, K3-59 and K3-109 (Fig. 2C and D), were examined in the verification experiment (Table 4), which confirmed the observation that the lines K3-59 and K3-109 were as susceptible to $P$. hordei as L94. The RLP on these lines was very short, and hardly any early abortion was observed (Table 4). However, the prehaustorial resistance to the two inappropriate rust species was significantly higher than in L94 and nearly as high as that in the resistant parent $\mathrm{C}-123$. This indicates that genes causing prehaustorial abortion of the inappropriate rusts are not necessarily effective against $P$. hordei.

\section{DISCUSSION}

PR of barley to $P$. hordei is a polygenic trait (30). Some of the loci responsible for PR to $P$. hordei in 'Vada' have been recently mapped (32). The prehaustorial component of resistance to the inappropriate rust fungi is also a polygenic trait. The RILs showed a continuous segregation for the percentage of early aborted infection units (Figs. 1 and 2).

The objective to separate the prehaustorial and posthaustorial components of resistance to the two inappropriate rust species by microscopic observations proved useful. Zhang et al. (41) measured infectibility macroscopically, so low infectibility could be due to either early hypersensitivity or to early prehaustorial abortion. Indeed, we observed in the RILs that a variable proportion of infection units arrested early in association with a very early hypersensitive reaction. Such infection units will not result in macroscopically visible infection sites. In the macroscopic study, the early hypersensitivity would have masked the association between the prehaustorial components of resistance. In our study, the correlation coefficients were, therefore, generally higher than in the study of Zhang et al. (41) (Table 2). The association was particularly

TABLE 3. Percentage of early aborted infection units not associated with plant cell necrosis of two inappropriate leaf rust species on five barley lines, measured in two experiments (I and II) ${ }^{\mathrm{a}}$

\begin{tabular}{llllll}
\hline & \multicolumn{2}{c}{ Puccinia recondita f. sp. tritici } & & \multicolumn{2}{l}{ Puccinia hordei-murini } \\
\cline { 2 - 3 } \cline { 5 - 6 } Line & Exp. I & Exp. II & & Exp. I & Exp. II \\
\hline K4-90 & $69 \mathrm{w}^{\mathrm{c}}$ & $70 \mathrm{y}$ & & $\underline{85} \mathrm{yz}^{\mathrm{d}}$ & $\underline{81} \mathrm{y}$ \\
K4-52 & $49 \mathrm{w}$ & $49 \mathrm{wx}$ & & $\underline{66} \mathrm{xy}$ & $\underline{62} \mathrm{x}$ \\
K4-109 & $\underline{71} \mathrm{wx}$ & $\underline{61} \mathrm{x}$ & & $50 \mathrm{wx}$ & $33 \mathrm{w}$ \\
L94 & $50 \mathrm{w}$ & $42 \mathrm{w}$ & & $36 \mathrm{w}$ & $29 \mathrm{w}$ \\
'Vada' & $81 \mathrm{x}$ & $80 \mathrm{z}$ & & $92 \mathrm{z}$ & $83 \mathrm{y}$ \\
\hline
\end{tabular}

${ }^{\mathrm{a}} \mathrm{I}=$ Data from the experiment presented in Figure 1A. II = Data from the verification experiment.

b The K4- lines are derived from the cross L94 $\times$ 'Vada'.

c Values in each column followed by the same letter are not significantly different $(P \leq 0.05)$ according to Duncan's multiple range test.

$\mathrm{d}$ The underlined figures indicate prehaustorial resistance that occurs specifically to one of either rust species.
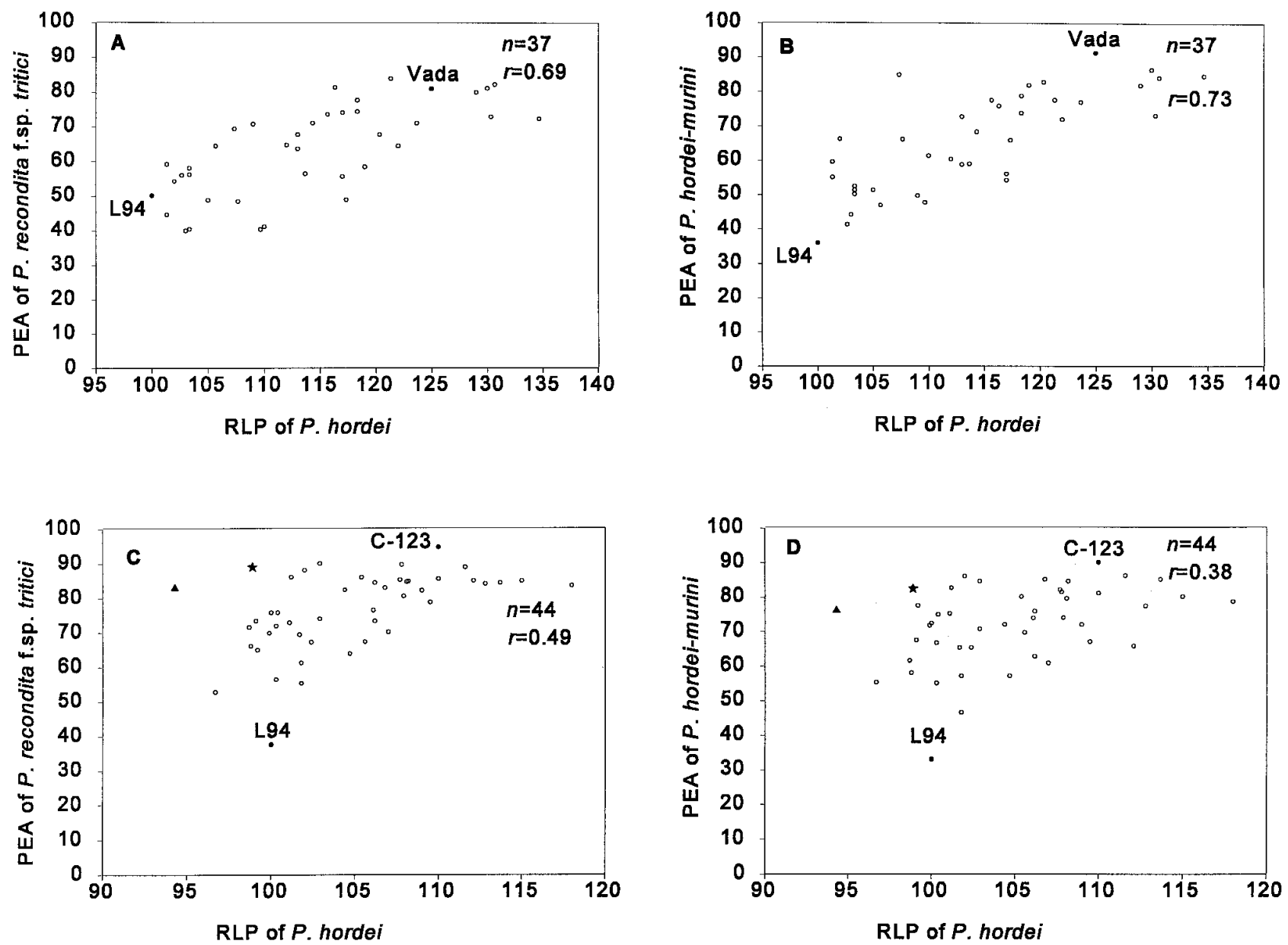

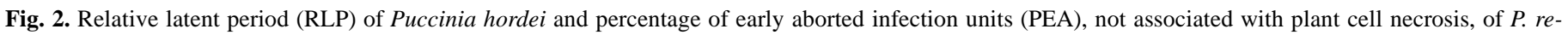

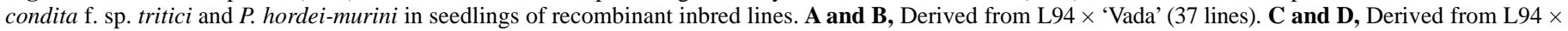
C-123 (44 lines). $\boldsymbol{\Delta}=$ line K3-59, and $\star=$ line K3-109. 
TABLE 4. Relative latent period (RLP) and percentage of early aborted infections units (PEA) not associated with plant cell necrosis of three species of rust fungus on four barley lines, measured in two experiments (I and II $)^{\mathrm{a}}$

\begin{tabular}{|c|c|c|c|c|c|c|c|}
\hline \multirow[b]{3}{*}{ Line } & \multicolumn{3}{|c|}{ Puccinia hordei } & \multirow{2}{*}{\multicolumn{2}{|c|}{$\frac{\text { Puccinia recondita f. sp. tritici }}{\text { PEA }}$}} & \multirow{2}{*}{\multicolumn{2}{|c|}{$\frac{\text { Puccinia hordei-murini }}{\text { PEA }}$}} \\
\hline & \multicolumn{2}{|c|}{ RLP } & \multirow{2}{*}{$\frac{\text { PEA }}{\text { Exp. II }}$} & & & & \\
\hline & Exp. I & Exp. II & & Exp. I & Exp. II & Exp. I & Exp. II \\
\hline K3-109 & $99 \mathrm{y}$ & 98 xy & $0 \mathrm{x}$ & $89 \mathrm{y}$ & $83 \mathrm{yz}$ & $83 \mathrm{y}$ & $73 \mathrm{z}$ \\
\hline L94 & $100 \mathrm{y}$ & $100 \mathrm{y}$ & $1 \mathrm{x}$ & $38 \mathrm{x}$ & $42 \times$ & $33 x$ & $29 x$ \\
\hline C-123 & $110 \mathrm{z}$ & $136 \mathrm{z}$ & $37 \mathrm{y}$ & $95 \mathrm{y}$ & $90 \mathrm{z}$ & $90 \mathrm{y}$ & $76 \mathrm{z}$ \\
\hline
\end{tabular}

${ }^{\mathrm{a}} \mathrm{I}=$ Data from the experiment presented in Figure 2C and D. II = Data from the verification experiment.

$\mathrm{b}$ The K3- lines are derived from the cross L94 $\times$ C-123.

'Values in each column followed by the same letter are not significantly different $(P \leq 0.05)$ according to Duncan's multiple range test.

higher in the RILs derived from L94 $\times$ 'Vada' inoculated with $P$. hordei-murini when the effects of the posthaustorial component of resistance were excluded.

In the RILs derived from L94 $\times$ 'Vada', the association between long LP of $P$. hordei and prehaustorial resistance to either of the inappropriate rust species was high. In the RILs from L94 $\times$ C-123, the association was also significant. In RILs with a long LP of $P$. hordei, the prehaustorial resistance to the inappropriate rust species was especially high (Fig. 2A to D). This indicates that genes for PR to $P$. hordei are also effective against inappropriate rust fungi or that they are linked to genes for resistance to inappropriate rust fungi.

There is also evidence that some genes that increase the prehaustorial resistance to inappropriate rust fungi are not effective against $P$. hordei. First, it is clear that in line L94, which has no prehaustorial resistance to $P$. hordei (Table 4), a substantial level of prehaustorial resistance to $P$. recondita $\mathrm{f}$. sp. tritici and $P$. hordei-murini is present (Tables 1 and 4). Second, RILs with a short LP could have a relatively high level of prehaustorial resistance to the inappropriate rusts (Table 4). This was observed in RILs from the cross L94 $\times$ C-123 (Fig. 2C and D). This indicates that C-123, especially, contains genes for prehaustorial resistance to the inappropriate rusts that are not effective against $P$. hordei.

We also found evidence that resistance to the two inappropriate rusts may still be specific. Especially in RILs from the cross L94 $\times$ 'Vada', genes that are effective against one of the two inappropriate rust species might not be effective against the other (Table 3, Fig. 1A). Most of the genes for prehaustorial resistance in C-123 are probably effective against both inappropriate rust species.

There are few other studies that report differences in the level of prehaustorial resistance to inappropriate rust or powdery mildew fungi. Tosa and Shishiyama (39), for example, reported that five barley cultivars differed substantially in their ability to arrest the development of the wheat powdery mildew fungi (E. graminis $\mathrm{f}$. sp. tritici) before the formation of haustoria. Such studies have not been followed up with reports on the genetics or the specificity of this resistance. The barley lines that were used in the current work will be very useful to study the genetics of resistance to inappropriate rust fungi. Qi et al. (32) already mapped the genes for PR to P. hordei in the RILs derived from L94 × 'Vada'. Additional marker analysis and histological screening of the complete sets of RILs produced from the two crosses would be needed to map genes for prehaustorial resistance to both inappropriate rust species. Such a study will unravel the genetics and rust specificity of the genes involved in the prehaustorial resistance of barley to inappropriate rust fungi.

\section{ACKNOWLEDGMENTS}

We thank P. Lindhout and X. Qi for their helpful suggestions during the preparation of the manuscript.

\section{LITERATURE CITED}

1. Anikster, Y. 1989. Host specificity versus plurivority in barley leaf rusts and their microcyclic relatives. Mycol. Res. 93:175-181.

2. Burr, B., and Burr, F. A. 1991. Recombinant inbreds for molecular map- ping in maize. Trends Genet. 7:55-60.

3. Bushnell, W. R., and Rowell, J. B. 1981. Suppressors of defense reactions: A model for roles in specificity. Phytopathology 71:1012-1014.

4. Deverall, B. J. 1989. Tansley review no. 18. Mechanisms of resistance and pathogenic specialization in rust-wheat interactions. New Phytol. 113:233-244.

5. Elmhirst, J. F., and Heath, M. C. 1987. Interactions of the bean rust and cowpea rust fungi with species of the Phaseolus-Vigna plant complex. I. Fungal growth and development. Can. J. Bot. 65:1096-1107.

6. Heath, M. C. 1977. A comparative study on non-host interactions with rust fungi. Physiol. Plant Pathol. 10:73-88.

7. Heath, M. C. 1981. A generalized concept of host-parasite specificity. Phytopathology 71:1121-1123.

8. Heath, M. C. 1981. Resistance of plants to rust infection. Phytopathology 71:971-974.

9. Heath, M. C. 1991. Tansley review no. 33. Evolution of resistance to fungal parasitism in natural ecosystems. New Phytol. 119:331-343.

10. Heath, M. C. 1991. The role of gene-for-gene interactions in the determination of host species specificity. Phytopathology 81:127-130.

11. Johnson, L. E. B., Bushnell, W. R., and Zeyen, R. J. 1982. Defense patterns in nonhost higher plant species against two powdery mildew fungi. I. Monocotyledonous species. Can. J. Bot. 60:1068-1083.

12. Johnson, R., and Lovell, N. K. 1994. Genetics of resistance of wheat to barley attacking races of Puccinia striiformis. Cereal Rusts Powdery Mildews Bull. 22:32-40.

13. Kunoh, H., Kuno, K., and Ishizaki, H. 1985. Cytological studies of the early stages of powdery mildew in barley and wheat. XI. Autofluorescence and haloes at penetration sites of appressoria of Erysiphe graminis hordei and Erysiphe pisi on barley coleoptiles. Can. J. Bot. 63:1535-1539.

14. Leath, K. T., and Rowell, J. B. 1966. Histological study of the resistance of Zea mays to Puccinia graminis. Phytopathology 56:1305-1309.

15. Luke, H. H., Barnett, R. D., and Pfahler, P. L. 1987. Xenoparasite-nonhost reactions in Puccinia-Gramineae pathosystems. Phytopathology 77: 1488-1491.

16. Mains, E. B. 1933. Host specialization in the leaf rust of grasses, Puccinia rubigo-vera. Pap. Mich. Acad. Sci. Arts Lett. 17:289-394.

17. Martens, J. W., Green, G. J., and Buchannon, K. W. 1983. Inheritance of resistance to Puccinia graminis f. sp. avenae in a Hordeum vulgare selection. Can. J. Plant Pathol. 5:266-268.

18. Moerschbacher, B. M., Noll, U., Ocampo, C. A., Flott, B. E., Gotthardt, U., Wüstefeld, A., and Reisener, H. J. 1990. Hypersensitive lignification response as the mechanism of non-host resistance of wheat against oat crown rust. Physiol. Plant. 78:609-615.

19. Niks, R. E. 1982. Early abortion of colonies of leaf rust, Puccinia hor$d e i$, in partially resistant barley seedlings. Can. J. Bot. 60:714-723.

20. Niks, R. E. 1983. Comparative histology of partial resistance and the nonhost reaction to leaf rust pathogens in barley and wheat seedlings. Phytopathology 73:60-64.

21. Niks, R. E. 1983. Haustorium formation by Puccinia hordei in leaves of hypersensitive, partially resistant, and nonhost plant genotypes. Phytopathology 73:64-66.

22. Niks, R. E. 1986. Failure of haustorial development as a factor in slow growth and development of Puccinia hordei in partially resistant barley seedlings. Physiol. Mol. Plant Pathol. 28:309-322.

23. Niks, R. E. 1987. Nonhost plant species as donors for resistance to pathogens with narrow host range. I. Determination of nonhost status. Euphytica 36:841-852.

24. Niks, R. E. 1988. Nonhost plant species als donors for resistance to pathogens with narrow host range. II. Concepts and evidence on the genetic basis of nonhost resistance. Euphytica 37:89-99.

25. Niks, R. E., and Dekens, R. G. 1991. Prehaustorial and posthaustorial resistance to wheat leaf rust in diploid wheat seedlings. Phytopathology 81:847-851. 
26. Niks, R. E., Kerckhoffs, B. M. F. J., and De la Rosa, R. 1996. Susceptibility of cultivated and wild barley (Hordeum vulgare sensu lato) to the leaf rust fungi of wheat and wall barley. Cereal Rusts Powdery Mildews Bull. 24:3-10.

27. Niks, R. E., and Kuiper, H. J. 1983. Histology of the relation between minor and major genes for resistance of barley to leaf rust. Phytopathology 73:55-59.

28. Niks, R. E., and Parlevliet, J. E. 1979. Variation for partial resistance to Puccinia hordei in the barley composite XXI. Cereal Rusts Bull. 6:3-10.

29. Niks, R. E., and Rubiales, D. 1994. Avirulence factors corresponding to barley genes $\mathrm{Pa} 3$ and $\mathrm{Pa} 7$ which confer resistance against Puccinia hordei in rust fungi other than $P$. hordei. Physiol. Mol. Plant Pathol. 45:321-331.

30. Parlevliet, J. E. 1979. Further evidence of polygenic inheritance of partial resistance in barley to leaf rust, Puccinia hordei. Euphytica 27:369-379.

31. Parlevliet, J. E. 1981. Race-non-specific disease resistance. Pages 47-54 in: Strategies for the Control of Cereal Disease. J. F. Jenkyn and R. T. Plumb, eds. Blackwell Scientific Ltd., Oxford.

32. Qi, X., Niks, R. E., Stam, P., and Lindhout, P. Identification of QTLs for partial resistance to leaf rust (Puccinia hordei) in barley. Theor. Appl. Genet. In press.

33. Riley, R., and Macer, R. C. F. 1966. The chromosomal distribution of the genetic resistance of rye to wheat pathogens. Can. J. Genet. Cytol. 8: 640-653.

34. Rohringer, R., Kim, W. K., Samborski, D. J., and Howes, H. K. 1977.
Calcofluor: An optical brightener for fluorescence microscopy of fungal plant parasites in leaves. Phytopathology 67:808-810.

35. Tosa, Y. 1989. Evidence on wheat for gene-for-gene relationship between formae speciales of Erysiphe graminis and genera of gramineous plants. Genome 32:918-924.

36. Tosa, Y. 1992. A model for the evolution of formae speciales and races. Phytopathology 82:728-730.

37. Tosa, Y., Akiyama, T., and Ogura, H. 1990. Cytological aspects of interactions between formae speciales of Erysiphe graminis and genera of gramineous plants, and their evolutionary implications. Can. J. Bot. 68: 1249-1253.

38. Tosa, Y., Mise, K., and Shishiyama, J. 1985. Recognition of two formae speciales of Erysiphe graminis by wheat cells. Ann. Phytopathol. Soc. Jpn. 51:223-226.

39. Tosa, Y., and Shishiyama, J. 1984. Defense reactions of barley cultivars to an inappropriate forma specialis of the powdery mildew fungus of gramineous plants. Can. J. Bot. 62:2114-2117.

40. Tosa, Y., Tsujimoto, H., and Ogura, H. 1987. A gene involved in the resistance of wheat to wheatgrass powdery mildew fungus. Genome 29: $850-852$.

41. Zhang, H. S., De la Rosa, R., Rubiales, D., Lubbers, H. H., Molenveld, J. W., and Niks, R. E. 1994. Role of partial resistance to Puccinia hordei in barley in the defence of barley to inappropriate rust fungi. Physiol. Mol. Plant Pathol. 45:219-228. 